Original Research

\title{
Chemical Composition, Antioxidant and Antibacterial Activity of Tunisian Date Palm Seed
}

\author{
Mounira Metoui $^{1,2 *}$, Awatef Essid ${ }^{1}$, Amira Bouzoumita ${ }^{1}$, Ali Ferchichi ${ }^{3}$ \\ ${ }^{1}$ Arid lands and Oases Cropping Laboratory, Arid Regions Institute of Medenine, Tunisia \\ ${ }^{2}$ Faculty of Mathematics, Physics, and Natural Sciences of Tunis University \\ ${ }^{3}$ Rural Laboratory, National Institute of Agronomics of Agronomic of Tunisia
}

Received: 8 December 2017

Accepted: 30 January 2018

\begin{abstract}
The seeds of 11 common dates (phoenix dactylifera L.) cultivars from the coastal oasis of Gabés, and the noble variety Deglet Nour from the oasis of Kébéli were evaluated for their chemical composition. Polyphenol, flavonoid, anthocyanin, antioxidant, and antimicrobial activity was recorded against 5 pathogen bacteria (Escherichia coli, staphylococcus aureus, staphylococcus epidermis, and Salmonella Typhinurium). The sugar content ranged between $1.20 \mathrm{~g} / 100 \mathrm{gMS}$ (Bouhattam) and $3.80 \mathrm{~g} / 100 \mathrm{gMS}$ (Khadhouri). The total phenolic content oscillates between $5.224 \mathrm{~g} / 100 \mathrm{gMS}$ (Baht) and $9.532 \mathrm{~g} / 100 \mathrm{gMS}$ (Khadhouri). Khadhouri also had the highest total flavonoids content (3.82 g/100 gMS). The higher antioxidant activity was found on the Khadhouri cultivar (55.47\% of DPPH radical scavenging activity). It has been found that a linear relationship $(\mathrm{p}<0.01)$ exists between total phenolic content and inhibition percentage. Antibacterial avtivities clearly show that all the extracts showed antibacterial activity except Enterococcus feacalis. PCA revealed that the first two principal components (PC1 and PC2) accounted for $54.23 \%$ of the total variance within the data set. These two principal components separated the studied cultivars into four different groups. This by-product of date processing industries could be regarded as an excellent source of food ingredients with interesting technological functionality that could also be used in medicinal preparation as an important source of oil.
\end{abstract}

Keywords: date palm seed, chemical composition, antioxidant, antibacterial, Tunisia

\section{Introduction}

Date palm (Phoenix dactylifera $\mathrm{L}$.) is an important crop in arid and semiarid regions. Date palm fruits constitute the principal source of remuneration and the

*e-mail: mounira.metoui@yahoo.com

basis of the economy for people living in the Tunisian Sahara. Phoenix dactylifera is a member of the family Arecaceae, also known as Palmaceae. It is well known that the average weight of date seeds is about $10-15 \%$ of date weight [1]. The fruit of the date palm is composed of a fleshy pericarp and seed. The edible part of date fruit is fleshy mesocarp, which exists in-between the epicarp and hard endocarp. Mesocarp of date fruit has more than $80 \%$ sugars and the remaining $20 \%$ has dietetic fibers, protein, 
lipids, and ash [2]. Date seeds may have extractible high value-added components. However, very little use is made of these components: they are discarded or used in animal feed. Little research has been undertaken on date seeds; this has focused particularly on their chemical [3]. Authors reported that chemical composition of date has $3.1-7.1 \%$ moisture, $2.3-6.4 \%$ protein, $5.0-13.2 \%$ fat, and $0.9-1.8 \%$ ash. Seed also contains the highest levels of phenolic (3,102-4,430 mg Gallic acid equivalent /100 g), antioxidant (580-929 $\mu \mathrm{m}$ trolox equivalent/g) and dietary fiber (78-80 g/100 g) [4]. Phenolic compounds have been shown to possess such benefits as being antioxidant, anticarcinogenic, antimicrobial, and anti-inflammatory [5].

The antioxidant can prevent oxidative damages caused by increased intakes from diet, and reduce the risk of chronic diseases. As some synthetic antioxidants may exhibit toxicity, requiring high manufacturing costs with lower efficiency than natural antioxidants, there is a need to identify more sources of natural phenolic antioxidants incorporated in food. Since a large quantity of date seed contains a significant amount of bioactive phenolic, the aim of this study was to evaluate chemical and mineral composition and phenolic, flavonoid, and anthocyanin content as well as the antioxidant and antibacterial activities of date seed of some cultivars in the maritime oasis of Gabes and the noble variety Deglet Nour from Kébéli.

\section{Experimental}

\section{Plant Material}

This study was conducted on 11 cultivars of date palm from the coastal oasis of Gabes, collected at the "tamr stage," and Deglet Nour from the oasis of Kébéli. The seeds were separated from the fruits, washed with distilled water, air dried, and ground into powder before being conserved at $-20^{\circ} \mathrm{C}$.

\section{Proximate Composition of Date Seeds}

Dry matter was determined according to the Association Official Analytical Chemists Total nitrogen using the Kjeldahl method. Protein amount was calculated using a factor of 6.25 . Sugars were extracted with methanol $(80 \%)$ by shaking at $70^{\circ} \mathrm{C}$ for $30 \mathrm{~min}$. After centrifuging, the supernatant was collected and the sugar content was analyzed with phenol/sulfuric acid reagent [6]. Fat content was extracted in Soxhlet extraction with petroleum ether for $6 \mathrm{~h}$ at boiling point of the solvent $\left(40-60^{\circ} \mathrm{C}\right)$ [7].

Determining dietary fiber was carried out using an AOAC enzymatic gravimetric official method. The sample was de-sugared by three extractions each with $85 \%$ ethanol $(10 \mathrm{ml} \backslash \mathrm{g})$ and then dried overnight at $40^{\circ} \mathrm{C}$

\section{Ash and Mineral Analysis}

About $1 \mathrm{~g}$ (powdered) of each sample, in a porcelain container, was ignited and incinerated in the muffle furnace at about $550^{\circ} \mathrm{C}$ for $8 \mathrm{~h}$. The total ash was expressed as a percentage of dry weight. The mineral constituents $(\mathrm{Na}, \mathrm{K})$ present in the date seeds were analyzed using a flame photometer. Phosphorus content (P) was determined by the phosphomolybdovanate method.

\section{Total Phenolic}

For optimizing seed extraction the dried samples were subjected to extraction at a constant stirring rate of $120 \mathrm{rpm}$ using a magnetic stirrer plate, water, and 50\% aqueous acetone solvents. The extraction procedure was previously described by [8].

The total phenolic content of seed extracts was determined according to Folin-Ciocalteu's method. One milliliter of seed extracts was mixed with $1 \mathrm{ml}$ of Folin-Ciocalteu's phenol, and after $5 \mathrm{~min} 10 \mathrm{ml}$ of $7 \%$ sodium carbonate solution (w/v) was added, and the final volume was made up to $25 \mathrm{ml}$ dionized water. After $1 \mathrm{~h}$ at room temperature, the absorbance was read at $750 \mathrm{~nm}$ using a thermo spectrophotometer. Measurements were calibrated to a standard curve of prepared Gallic acid solution. The total phenolic concentration was expressed as grams of Gallic acid equivalent per $100 \mathrm{~g}$ of the sample on a weight basis.

\section{Total Flavonoid}

The total flavonoid of extract seed was determined according to [8]. One milliliter of extract seed was mixed with $5 \mathrm{ml}$ deionized water and then $0.3 \mathrm{ml}$ of $5 \%$ sodium nitrite was added, followed by $1 \mathrm{M}$ aluminum chloride after $5 \mathrm{~min}$. The mixer was diluted with deionized water to a final volume of $10 \mathrm{ml}$. After mixing, the absorbance at $510 \mathrm{~nm}$ was immediately read using a thermo spectrophotometer. Measurements were calibrated to a standard curve of prepared catechin solution. The total flavonoid content was expressed as grams of catechin equivalent per $100 \mathrm{~g}$ of sample on a wet weight basis.

\section{Determining Total Anthocyanin Content}

Total anthocyanin content was determined by $\mathrm{pH}$ differential method using two buffer systems: potassium chloride buffer $(\mathrm{pH} 1.0,0.025 \mathrm{M})$ and sodium acetate

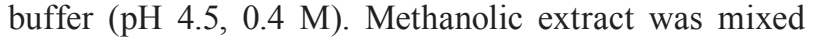
with $3.6 \mathrm{ml}$ of corresponding buffers and read against water as a blank at 510 and $700 \mathrm{~nm}$ [9]. Absorbance (A) was calculated using this formula:

$$
\mathrm{A}=[(\mathrm{A} 510-\mathrm{A} 700) \mathrm{pH} 1.0-(\mathrm{A} 510-\mathrm{A} 700) \mathrm{pH} 4.5]
$$

...with a molar extinction coefficient of 2960 . 
Results Were Expressed as mg of Cyanidin-3glucoside equivalents (CGE) per g dry weight.

\section{Radical Scavenging Activity on DPPH}

Free radical scavenging capacity was determined with 1.1-diphenylhy-drazyl (DPPH). An aliquot of each tested extract was mixed with $23.6 \mu \mathrm{g} \mathrm{ml}{ }^{1}$ of DPPH solution (in ethanol) (v.v- $\left.{ }^{1}\right)$. After incubation for $30 \mathrm{~min}$, the absorbance was read at $517 \mathrm{~nm}$. Ascorbic acid was used as a control. Antioxidant activity was calculated using the equation:

$$
\% \text { Antioxidant activity }=100 \times\left(1-\mathrm{A}_{\mathrm{ech} /} \mathrm{A}_{\mathrm{c}}\right)
$$

...where $\mathrm{A}_{\text {ech }}$ is the absorbance of the sample and $\mathrm{A}_{\mathrm{c}}$ is the absorbance of the sample.

\section{Antibacterial Activity}

Date seeds were tested against E .coli ATCC 35218, Salmonella Typhinurium ATCC 1408, Enterococcus feacalis ATCC 29212, Staphylococcus aureus ATCC 25923, Staphylococcus epidermis CIP 106510. Date seed extracts were dissolved in three different solvents (water, methanol, and acetone) and sterilized by filtration on $0.45 \mathrm{~mm}$ Millipore filters. The disc diffusion method was employed for determining antibacterial activity of the extracts. A total of $100 \mathrm{ml}$ of suspensions containing $10^{6} \mathrm{CFU} / \mathrm{ml}$ of bacteria, in exponential growth phase, on Mueller-Hinton agar medium.

Filter paper disks $(9 \mathrm{~mm}$ of diameter $)$ were impregnated with $50 \mathrm{ml}$ of each extract $(7.5 \mathrm{mg} / \mathrm{disc})$ and placed on the inoculated Petri dishes. Negative control was performed using different solvents (water, methanol, and acetone) employed to dissolve the different extracts. Ciprofloxacin (100 mg/disc), oxacillin (500 mg/disc), and lamidaz (100 mg/disc) were individually used as positive controls for bacteria. Petri dishes were then incubated during 24 $\mathrm{h}$ at $37^{\circ} \mathrm{C}$ for bacterial strains. Antibacterial activity was evaluated by measuring the inhibition zone (mm) against the studied microorganisms, including disc diameter [10].

\section{Statistical Method}

All analytical determinations were performed in triplicate. Statistical analysis was performed using XLSTAT_ pro 7.5. Data obtained was analyzed using analysis of variances to determine the significance $(p<0.05)$ of the main effects, followed by Tukey's multiple comparison test for significance of difference. Values of different parameters were expressed as the mean \pm standard deviation. PCA and UPGMA cluster analysis were performed with NTSYS 2.11 software (Exeter Software, Stauket, NY).

\section{Results and Discussion}

\section{Proximate Analyses}

Although the moisture content shown in Table 1 ranged between $17.18 \%$ for Rochdi variety and $29.47 \%$ for Lemsi variety, this content of water could reach its highest value in other varieties, like moisture concentrations of Deglet Noor at $13.06 \%$. The above differences in moisture content may be attributed to the variability of varieties and especially to the origin of cultivars. Differences observed for the same cultivar are due mainly to the climate conditions, harvesting period, and drying conditions and storage. The rate of moisture is reduced from $85 \%$ at the first stage to

Table 1. Chemical composition (dry basis) of date seeds from the 12 studied cultivars.

\begin{tabular}{|c|c|c|c|c|c|}
\hline Cultivars & Protein (\%) & Fat $(\%)$ & Moisture (\%) & Dietary fiber (\%) & Sugar (\%) \\
\hline Lemsi & $5.44 \pm 0.12^{\mathbf{E F}}$ & $4.97 \pm 0.04^{\mathrm{G}}$ & $25.23 \pm 0.05^{\mathrm{D}}$ & $75.48 \pm 0.32^{\mathbf{E F G}}$ & $1.86 \pm 0.02^{\mathrm{G}}$ \\
\hline Amari & $6.48 \pm 0.22^{\mathrm{BC}}$ & $5.95 \pm 0.07^{\mathrm{E}}$ & $19.39 \pm 0.04^{\mathrm{G}}$ & $73.83 \pm 0.33^{\mathbf{H}}$ & $2.56 \pm 0.02^{E}$ \\
\hline Hammouri & $6.82 \pm 0.03^{\mathrm{AB}}$ & $6.81 \pm 0.04^{\mathrm{C}}$ & $18.46 \pm 0.15^{\mathrm{H}}$ & $75.78 \pm 0.04^{\mathrm{DE}}$ & $1.88 \pm 0.03^{\mathrm{G}}$ \\
\hline Korkobi & $6.96 \pm 0.01^{\mathrm{A}}$ & $5.23 \pm 0.06^{\mathbf{F}}$ & $19.63 \pm 0.09^{\mathrm{G}}$ & $76.56 \pm 0.21^{\mathbf{D}}$ & $3.17 \pm 0.03^{\mathrm{C}}$ \\
\hline Matata & $5.76 \pm 0.01^{\mathrm{DE}}$ & $4.88 \pm 0.08^{\mathrm{G}}$ & $29.47 \pm 0.04^{\mathrm{B}}$ & $79.54 \pm 0.01^{\text {B }}$ & $3.44 \pm 0.01^{\text {B }}$ \\
\hline Halwaya & $7.02 \pm 0.01^{\mathrm{A}}$ & $7.81 \pm 0.04^{\mathrm{A}}$ & $17.8 \pm 0.07^{\mathrm{I}}$ & $75.6 \pm 0.16^{\mathrm{DE}}$ & $2.82 \pm 0.01^{\mathrm{D}}$ \\
\hline Rochdi & $6.13 \pm 0.05^{\mathrm{CD}}$ & $6.7 \pm 0.12^{\mathrm{C}}$ & $22.16 \pm 0.04^{\mathrm{F}}$ & $74.71 \pm 0.36^{\mathrm{FGH}}$ & $3.41 \pm 0.07^{\mathrm{B}}$ \\
\hline Deglet Nour & $5.51 \pm 0.01^{\mathrm{EF}}$ & $7.4 \pm 0.05^{\text {B }}$ & $23.55 \pm 0.22^{\mathbf{E}}$ & $78.4 \pm 0.27^{\mathrm{C}}$ & $2.68 \pm 0.02^{\mathrm{E}}$ \\
\hline Baht & $5.23 \pm 0.02^{\mathbf{F}}$ & $4.93 \pm 0.01^{\mathrm{FG}}$ & $27.72 \pm 0.04^{\mathrm{C}}$ & $75.83 \pm 0.01^{\mathrm{DE}}$ & $2.12 \pm 0.01^{\mathrm{F}}$ \\
\hline Bouhattam & $5.65 \pm 0.01^{\mathrm{E}}$ & $5.06 \pm 0.01^{\mathrm{FG}}$ & $33.61 \pm 0.06^{\mathrm{A}}$ & $78.77 \pm 0.01^{\mathrm{BC}}$ & $1.21 \pm 0.01^{\mathrm{H}}$ \\
\hline Eguiwa & $6.96 \pm 0.01^{\mathrm{A}}$ & $5.9 \pm 0.06^{\mathbf{E}}$ & $16.06 \pm 0.03^{\mathrm{K}}$ & $74.46 \pm 0.01^{\mathrm{GH}}$ & $1.74 \pm 0.02^{\mathrm{G}}$ \\
\hline Khadhouri & $6.72 \pm 0.01^{\mathrm{AB}}$ & $6.4 \pm 0.03^{\mathrm{D}}$ & $17.18 \pm 0.01^{\mathrm{J}}$ & $82.37 \pm 0.01^{\mathbf{A}}$ & $3.81 \pm 0.01^{\mathrm{A}}$ \\
\hline
\end{tabular}


$24 \%$ full ripeness during the development of dates. Sometime it is equal to and/or closely related to relative humidity of the atmosphere [2]. Date pits from our different varieties contained 5.23-6. 96\% protein. These results were more important than those reported by [3] that showed a Saudi date variety with a protein level of $3.12 \%$. Since the protein content in date pits is small and the proteins may not be very digestible, date pit proteins need to be investigated further to explain their poor solubility and to recover them for potential food use.

The date seed containing a significant amount of fat ranged between $4.88 \%$ for Matata variety and $7.81 \%$ for Halwaya variety. A significant difference $(p<0.05)$ in fat content were observed between the different studied cultivars. Amari contained the highest fat content $7.81 \%$ and Lemsi contained less content at $4.88 \%$. These results were more than those reported by El-Rahman, who found that date seeds contained high levels of crude oil, being 5.95 and 6.4 times as high as that in date fruits of palm shell, respectively [3]. [11] reported that fat in different date varieties ranged from $0.1 \%$ to $0.5 \%$. This percentage favors the extraction of seed oil, which has many benefits. The study of two Tunisian cultivars by Besbes and her collaborative showed that date seed oils contain high relative percentages of oleic acid. They are also more yellow-colored than other vegetable oils and they can protect against UV light responsible for much cellular damage. Date seed oils could easily be conserved due to their high oxidative stability [7]. Regarding these specifics, the value of this by-product in the cosmetic and food industries may be justified. However, the antioxidant composition of date seed oil must be tested in order to more valorize this byproduct.

A significant difference $(p<0.05)$ in sugar content was observed between the different varieties. Khadhouri presented the highest quantities of sugar (3.8\%). Total sugars are in broad agreement with data of [12]. Those differences may be attributed to the variability of the studied cultivars. The difference among the 12 date seed varieties can be attributed to differences between cultivars, degree of ripeness, latitude, environmental conditions, processing techniques, and storage conditions. In our study, the highest amount of dietary fiber was noted in Deglet Nour varieties (82.37\%).

\section{Minerals Determination}

In our study, date seeds also contained a significant amount of important minerals (Table 2). Potassium was the highest mineral content in all samples ranging between $300 \mathrm{mg} / 100 \mathrm{~g}$ DW determined in Rochdi seeds, and $204.33 \mathrm{mg} / 100 \mathrm{~g}$ DW in Lemsi seeds, followed by phosphorus ranging between $124 \mathrm{mg} / 100 \mathrm{~g}$ DW determined in Rochdi seeds and $68.33 \mathrm{mg} / 100 \mathrm{~g}$ DW observed in Lemsi and Baht seeds. Sodium was the lowest, varying between $17.8 \mathrm{mg} / 100 \mathrm{~g}$ DW in Rochdi and $11.22 \mathrm{mg} / 100 \mathrm{~g} \mathrm{DW}$ in Baht.

XLSTAT-Pro7.5 showed the correlation between the different compounds of important minerals, determining that the highest significant correlation was between the phosphorus and potassium contents 0.94 in decreasing order by potassium-sodium 0.87 and phosphorus-sodium 0.85 .

In our study the potassium concentration was the highest followed in descending order by phosphorus and sodium, and this observation agrees with the claims of Abiola. However, the potassium, sodium, and calcium contents of the date seed are not as high as the amounts found in date fruits [13-14]. Date seeds, like their fruits, have relatively high potassium content $(78.12 \mathrm{mg} / 100 \mathrm{~g})$ compared to sodium content [15].

Table 2. Mineral composition of date seeds from the studied cultivars ( $\mathrm{mg} / 100 \mathrm{~g}$ dry weight).

\begin{tabular}{|c|c|c|c|c|}
\hline Cultivars & Ash & Sodium & Phosphorus & Potassium \\
\hline Lemsi & $0.92 \pm 0.01^{\mathrm{E}}$ & $10.61 \pm 0.01^{\mathrm{I}}$ & $68.33 \pm 0.33^{\mathrm{F}}$ & $204.33 \pm 2.6^{\mathrm{G}}$ \\
\hline Amari & $1.04 \pm 0.01^{\mathrm{D}}$ & $16.13 \pm 0.01^{\mathrm{C}}$ & $112 \pm 0.58^{\mathrm{B}}$ & $262.67 \pm 1.33^{\mathrm{D}}$ \\
\hline Hammouri & $1.27 \pm 0.01^{\mathrm{B}}$ & $16.18 \pm 0.01^{\mathrm{C}}$ & $120 \pm 0.58^{\mathrm{A}}$ & $280.67 \pm 0.67^{\mathrm{C}}$ \\
\hline Korkobi & $1.19 \pm 0.01^{\mathrm{C}}$ & $12.18 \pm 0.02^{\mathrm{F}}$ & $78.67 \pm 0.88^{\mathrm{DE}}$ & $223 \pm 1^{\mathrm{E}}$ \\
\hline Matata & $0.97 \pm 0.01^{\mathrm{E}}$ & $11.53 \pm 0.01^{\mathrm{G}}$ & $73.67 \pm 0.88^{\mathrm{EF}}$ & $214.33 \pm 0.33^{\mathrm{F}}$ \\
\hline Halwaya & $1.15 \pm 0.02^{\mathrm{C}}$ & $13.52 \pm 0.02^{\mathrm{D}}$ & $78.33 \pm 0.33^{\mathrm{DE}}$ & $218.67 \pm 0.88^{\mathrm{EF}}$ \\
\hline Rochdi & $1.35 \pm 0.03^{\mathrm{A}}$ & $17.83 \pm 0.01^{\mathrm{A}}$ & $124 \pm 0.58^{\mathrm{A}}$ & $300 \pm 1.15^{\mathrm{A}}$ \\
\hline Deglet Nour & $1.26 \pm 0.01^{\mathrm{B}}$ & $16.07 \pm 0.03^{\mathrm{C}}$ & $118 \pm 0.58^{\mathrm{AB}}$ & $289.33 \pm 0.33^{\mathrm{B}}$ \\
\hline Baht & $0.94 \pm 0.01^{\mathrm{E}}$ & $11.22 \pm 0.01^{\mathrm{H}}$ & $68.33 \pm 0.33^{\mathrm{F}}$ & $220.1 \pm 0.12^{\mathrm{E}}$ \\
\hline Bouhattam & $0.96 \pm 0.01^{\mathrm{E}}$ & $12.3 \pm 0.12^{\mathrm{F}}$ & $84 \pm 0.58^{\mathrm{D}}$ & $219 \pm 0.58^{\mathrm{EF}}$ \\
\hline Eguiwa & $1.14 \pm 0.01^{\mathrm{C}}$ & $13.3 \pm 0.06^{\mathrm{E}}$ & $120 \pm 3.46^{\mathrm{A}}$ & $290 \pm 0.58^{\mathrm{B}}$ \\
\hline Khadhouri & $1.26 \pm 0.01^{\mathrm{B}}$ & $16.7 \pm 0.06^{\mathrm{B}}$ & $99 \pm 1.15^{\mathrm{C}}$ & $287.47 \pm 0.26^{\mathrm{B}}$ \\
\hline
\end{tabular}


Total Polyphenols, Flavonoids, and Anthocyanin Content

Polyphenol contents of 12 varieties are presented in Table 3. The total phenols are expressed as mg Gallic acid equivalents per $g$ dry weight (g GAE/100g DW). A significant difference $(p<0.05)$ in total phenolic contents was observed between the different studied cultivars. Khadhouri contained the highest total phenolic content $(9,532 \mathrm{~g}$ of GAE $/ 100 \mathrm{~g})$, whereas Lemsi had the lowest total phenolic (5.13 g of GAE/100g). Phenolic was considered an effective antioxidant because they act as free radical captors or scavengers. Several research groups have reported that dates are rich in phenolic acids [16-17].

The results of phenolic contents were less than those reported by [4], who found $10.3 \mathrm{~g} / 100 \mathrm{~g}$ in varieties grown in Oman. However, the total phenol contents of seeds obtained from different date fruits changed between $1.98 \mathrm{mg}$ GAE/100 g (Barhi) and $4.65 \mathrm{mg} \mathrm{GAE} / 100 \mathrm{~g}$ (Soughi cv) [18]. The difference could be explained by various factors such as variety, growing condition, maturity, season, geographic origin, fertilizer, soil type, storage condition, amount of sunlight received, culture methods, process and stabilization conditions, use of different analytical methods, and use of different phenolic standards.

In comparison with date pulp, $2.5 \mathrm{mg} / 100 \mathrm{~g}$ reported by [3] seed may be considered a rich source of phenolic compounds. Because of the highest phenolic content, seeds could be used in functional foods, food additives, pharmaceuticals, and cosmetic industries [19]. In our study, total flavonoid ranged from $1.43 \mathrm{~g}$ $\mathrm{CAE} / 100 \mathrm{~g}$ DW in Lemsi variety to $3.83 \mathrm{~g} \mathrm{CAE} / 100 \mathrm{~g}$ DW in Korkobi variety. A significant difference $(\mathrm{p}<0.05)$ in total flavonoid contents was also observed between the different varieties. Flavonoids present in plants possess diverse health benefits, which include antioxidant and radical scavenging activities, reduction of certain chronic diseases, prevention of some cardiovascular disorders, and certain kinds of cancerous processes [20]. Flavonoids are found in a variety of fruits and vegetables with such notable health benefits as antioxidants and antiinflammatories [21].

The results of flavonoid contents were less than those reported by [4], who found $5.4 \mathrm{~g} / 100 \mathrm{~g}$ in varieties grown in Oman. Flavonoids present in plants possess diverse health benefits, which includes antioxidant and radical scavenging activities, reduction of certain chronic diseases, prevention of some cardiovascular disorders, and certain kinds of cancerous processes. This difference could be explained by the variability of the studied cultivars. Generally, flavonoid content is known to be highly dependent either on the cultivar or on the growing/processing condition [22].

Date seed content for total anthocyanin was different among different varieties with Baht $0.2 \mathrm{mg}$ of cyanidin-3-glucoside equivalents per $\mathrm{g}$ dry weight (mg CGE/g DW) being the lowest, while Deglet Nour 0.61 (mg CGE/g DW) was the highest.

\section{Free Radical Scavenging: Test DPPH}

The results of antioxidant capacity are shown in Table 3. In our study there are significant differences $(p<0.05)$ relative to the percentage of inhibition between the studied varieties. Khadhouri presented the highest antioxidant activity $(55.470 \%)$. The lowest activity was observed in Baht variety (33.120\%). Antioxidant capacity of date seed was significantly correlated with phenolic contents $(r=0.96)$ and with flavonoid values $(r=0.96)$, but not with anthocyanin values $(\mathrm{r}=0.42)(\mathrm{p}<0.05)$.

Table 3. Mean values of total polyphenols, flavonoids, anthocyanin, and DPPH of palm date seeds.

\begin{tabular}{|c|c|c|c|c|}
\hline Cultivars & $\begin{array}{c}\text { Polyphenol } \\
\text { g GAE/100g DW })\end{array}$ & $\begin{array}{c}\text { Flavonoid } \\
(\mathrm{g} \text { CAE/100g DW })\end{array}$ & $\begin{array}{c}\text { Anthocyanin } \\
(\mathrm{mg} \mathrm{CGE} / \mathrm{g} D W\end{array}$ & DPPH(\%) \\
\hline Lemsi & $5.13 \pm 0.01^{\mathrm{J}}$ & $1.43 \pm 0.02^{\mathrm{K}}$ & $0.25 \pm 0.02^{\mathrm{GH}}$ & $33.12 \pm 0.01^{\mathrm{K}}$ \\
\hline Amari & $8.14 \pm 0.01^{\mathrm{D}}$ & $3.22 \pm 0.01^{\mathrm{D}}$ & $0.32 \pm 0.01^{\mathrm{F}}$ & $50.45 \pm 0.02^{\mathrm{D}}$ \\
\hline Hammouri & $6.5 \pm 0.01^{\mathrm{G}}$ & $1.98 \pm 0.01^{\mathrm{H}}$ & $0.46 \pm 0.01^{\mathrm{CD}}$ & $40.56 \pm 0.01^{\mathrm{I}}$ \\
\hline Korkobi & $9.41 \pm 0.01^{\mathrm{B}}$ & $3.83 \pm 0.01^{\mathrm{A}}$ & $0.48 \pm 0.01^{\mathrm{C}}$ & $55.47 \pm 0.01^{\mathrm{A}}$ \\
\hline Matata & $7.13 \pm 0.01^{\mathrm{F}}$ & $2.39 \pm 0.03^{\mathrm{F}}$ & $0.53 \pm 0.02^{\mathrm{B}}$ & $42.13 \pm 0.01^{\mathrm{G}}$ \\
\hline Halwaya & $7.85 \pm 0.01^{\mathrm{E}}$ & $2.52 \pm 0.01^{\mathrm{E}}$ & $0.38 \pm 0.01^{\mathrm{E}}$ & $44.3 \pm 0.01^{\mathrm{F}}$ \\
\hline Rochdi & $8.72 \pm 0.02^{\mathrm{C}}$ & $3.23 \pm 0.02^{\mathrm{D}}$ & $0.46 \pm 0.01^{\mathrm{CD}}$ & $49.72 \pm 0.01^{\mathrm{E}}$ \\
\hline Deglet Nour & $7.14 \pm 0.01^{\mathrm{F}}$ & $2.31 \pm 0.01^{\mathrm{G}}$ & $0.61 \pm 0.01^{\mathrm{A}}$ & $41.32 \pm 0.01^{\mathrm{H}}$ \\
\hline Baht & $5.22 \pm 0.01^{\mathrm{I}}$ & $1.54 \pm 0.01^{\mathrm{J}}$ & $0.2 \pm 0.01^{\mathrm{H}}$ & $34.88 \pm^{\mathrm{J}}$ \\
\hline Bouhattam & $5.82 \pm 0.02^{\mathrm{H}}$ & $1.63 \pm 0.01^{\mathrm{I}}$ & $0.26 \pm 0.01^{\mathrm{G}}$ & $42.16 \pm 0.01^{\mathrm{G}}$ \\
\hline Eguiwa & $9.48 \pm 0.02^{\mathrm{A}}$ & $3.61 \pm 0.01^{\mathrm{C}}$ & $0.41 \pm 0.01^{\mathrm{DE}}$ & $51.52 \pm 0.01^{\mathrm{C}}$ \\
\hline Khadhouri & $9.53 \pm 0.01^{\mathrm{A}}$ & $3.68 \pm{ }^{\mathrm{B}}$ & $0.46 \pm 0.01^{\mathrm{CD}}$ & $54.58 \pm 0.01^{\mathrm{B}}$ \\
\hline
\end{tabular}


Table 4. Correlation between DPPH, flavonoid, polyphenol, and anthocyanin.

\begin{tabular}{|c|c|c|c|c|}
\hline & DPPH & Flavonoid & Polyphenol & Anthocyanin \\
\hline DPPH & 1 & & & \\
\hline Flavonoid & 0.96 & 1 & & \\
\hline Polyphenol & 0.96 & 0.99 & 1 & \\
\hline Anthocyanin & 0.42 & 0.47 & 0.54 & 1 \\
\hline
\end{tabular}

**Correlation is significant at the 0.05 level

Differences in the antioxidant capacity were explained by the khadhouri seed's, which have a higher level of polyphenol and flavonoid than the other cultivars. Date seed presented an interesting antioxidant capacity to scavenging DPPH free radicals and it seems to be used in food as an important antioxidant source. For example, caffeine is the active ingredient found in coffee beans (Coffea), showing biological activity in the treatment of central nervous system (CNS) disorders [23-24].

\section{Antibacterial Activities}

In the present investigation the antibacterial activities are given in Tables 5-6. Antimicrobial activity was recorded against five pathogen bacteria (Escherichia coli, staphylococcus aureus, staphylococcus epidermis, Salmonella Typhinurium, Enterococcus feacalis), which clearly show that all the extracts have shown antibacterial activity except Enterococcus feacalis.

The acetone and methanol extracts showed good antibacterial activity against Escherichia coli, staphylococcus aureus, staphylococcus epidermis, and
Salmonella Typhinurium, whereas water extract had very little effect on all test bacterial species.

Methanol extracts of date seed were the most effective against all tested bacteria, followed by acetone and aqueous extract.

The data on zone of inhibition demonstrate that Deglet Nour does not have the most antibacterial activity against gram-negative and gram-postive organisms, whereas common date like Bouhattam has an inhibition diameter $(22.43 \mathrm{~mm})$ against staphylococcus aureus and $19.43 \mathrm{~mm}$ against salmonella Typhinurium, matata $21.70 \mathrm{~mm}$ against staphylococcus epidermis, and korkobi $27.87 \mathrm{~mm}$ against Escherichia coli.

Methanol extract showed maximum zone of inhibition against Escherichia coli (27.87), followed by staphylococcus aureus, staphylococcus epidermis, and Salmonella Typhinurium $(22.33,21.70,19.43)$. Results are in agreement with the literature. Qualitatively, antibacterial activity is similar to previous findings [25].

[26] found an antimicrobial effect of blueberry extracts(rich in phenolics) against Listeria monocytogenes and Salmonella Enteritidis. The antibacterial activity of

Table 5. Antibacterial activity of different extracts of date palm seed against gram-negative organisms.

\begin{tabular}{|c|c|c|c|c|c|c|c|c|c|}
\hline \multicolumn{10}{|c|}{ Inhibition diameter $(\mathrm{mm})$} \\
\hline & \multicolumn{3}{|c|}{ Staphylococcus aureus } & \multicolumn{3}{|c|}{ Staphylococcus epidermis } & \multicolumn{3}{|c|}{ Enterococcus feacalis } \\
\hline & M & A & W & M & $\mathrm{A}$ & W & $\mathrm{M}$ & A & W \\
\hline Lemsi & $22.23^{\mathrm{A}}$ & $19.43^{\mathrm{B}}$ & $5.73^{\mathrm{E}}$ & $21.20^{\mathrm{BC}}$ & $18.57^{\mathrm{BC}}$ & $5.63^{\mathrm{D}}$ & --- & --- & --- \\
\hline Amari & $21.60^{\mathrm{B}}$ & $19.33^{\mathrm{BC}}$ & $5.30^{\mathrm{F}}$ & $20.57^{\mathrm{D}}$ & $19.20^{\mathrm{A}}$ & $6.63^{\mathrm{A}}$ & --- & --- & --- \\
\hline Hammouri & $19.93^{\mathrm{D}}$ & $18.43^{\mathrm{DE}}$ & $5.83^{\mathrm{DE}}$ & $21.03^{\mathrm{C}}$ & $18.60^{\mathrm{BC}}$ & $5.97^{\mathrm{CD}}$ & ---- & ---- & ---- \\
\hline Korkobi & $22.30^{\mathrm{A}}$ & $18.43^{\mathrm{DE}}$ & $6.63^{\mathrm{AB}}$ & $19.77^{\mathrm{E}}$ & $17.73^{\mathrm{E}}$ & $6.40^{\mathrm{AB}}$ & --- & --- & --- \\
\hline Matata & $18.67^{\mathrm{E}}$ & $17.50^{\mathrm{G}}$ & $6.50^{\mathrm{B}}$ & $21.70^{\mathrm{A}}$ & $18.30^{\mathrm{D}}$ & $6.10^{\mathrm{BC}}$ & --- & $\begin{array}{ll}--- \\
---\end{array}$ & 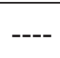 \\
\hline Halwaya & $19.60^{\mathrm{D}}$ & $17.77^{\mathrm{G}}$ & $6.63^{\mathrm{AB}}$ & $21.40^{\mathrm{B}}$ & $19.20^{\mathrm{A}}$ & $6.03^{\mathrm{BC}}$ & --- & --- & --- \\
\hline Rochdi & $20.73^{\mathrm{C}}$ & $18.07^{\mathrm{F}}$ & $6.13^{\mathrm{C}}$ & $20.60^{\mathrm{D}}$ & $18.30^{\mathrm{D}}$ & $6.60^{\mathrm{A}}$ & ---- & ---- & ---- \\
\hline Deglet Nour & $21.40^{\mathrm{B}}$ & $18.27^{\mathrm{EF}}$ & $6.07^{\mathrm{CD}}$ & $19.50^{\mathrm{E}}$ & $18.40^{\mathrm{CD}}$ & $5.93^{\mathrm{CD}}$ & --- & --- & --- \\
\hline Baht & $21.37^{\mathrm{B}}$ & $18.60^{\mathrm{D}}$ & $6.20^{\mathrm{C}}$ & $20.50^{\mathrm{D}}$ & $19.17^{\mathrm{A}}$ & $6.13^{\mathrm{BC}}$ & ---- & ---- & ---- \\
\hline Bouhattam & $22.43^{\mathrm{A}}$ & $19.07^{\mathrm{C}}$ & $6.67^{\mathrm{AB}}$ & $21.33^{\mathrm{B}}$ & $18.70^{\mathrm{B}}$ & $6.30^{\mathrm{ABC}}$ & ---- & ---- & ---- \\
\hline Eguiwa & $21.27^{\mathrm{BC}}$ & $19.37^{\mathrm{B}}$ & $6.50^{\mathrm{B}}$ & $20.60^{\mathrm{D}}$ & $18.50^{\mathrm{BCD}}$ & $6.40^{\mathrm{AB}}$ & ---- & ---- & ---- \\
\hline Khadhouri & $17.67^{\mathrm{F}}$ & $21.50^{\mathrm{A}}$ & $6.80^{\mathrm{A}}$ & $18.33^{\mathrm{F}}$ & $19.30^{\mathrm{A}}$ & $5.93^{\mathrm{CD}}$ & ---- & ---- & ---- \\
\hline
\end{tabular}


Table 6. Antibacterial activity of different extracts of date palm seed against gram-negative organisms.

\begin{tabular}{|c|c|c|c|c|c|c|}
\hline \multicolumn{7}{|c|}{ Inhibition diameter (mm) } \\
\hline & \multicolumn{3}{|c|}{ Salmonella thphimirum } & \multicolumn{3}{|c|}{ Escherichia coli } \\
\hline & $\mathrm{M}$ & A & W & $\mathrm{M}$ & A & W \\
\hline Lemsi & $\begin{array}{c}19.23 \\
\mathrm{~A}\end{array}$ & $16.87^{\mathrm{C}}$ & $6.67^{\mathrm{A}}$ & $21.27^{\mathrm{FG}}$ & $18.50^{\mathrm{DE}}$ & $6.13^{\mathrm{BC}}$ \\
\hline Amari & $18.37^{\mathrm{B}}$ & $16.33^{\mathrm{DE}}$ & $5.23^{\mathrm{D}}$ & $21.93^{\mathrm{E}}$ & $17.87^{\mathrm{F}}$ & $5.17^{\mathrm{FG}}$ \\
\hline Hammouri & $19.47^{\mathrm{A}}$ & $17.23^{\mathrm{B}}$ & $5.83^{\mathrm{C}}$ & $22.20^{\mathrm{DE}}$ & $18.53^{\mathrm{DE}}$ & $5.80^{\mathrm{CD}}$ \\
\hline Korkobi & $19.30^{\mathrm{A}}$ & $17.13^{\mathrm{B}}$ & $6.67^{\mathrm{A}}$ & $27.87^{\mathrm{A}}$ & $22.80^{\mathrm{B}}$ & $6.40^{\mathrm{AB}}$ \\
\hline Matata & $18.47^{\mathrm{B}}$ & $16.40^{\mathrm{DE}}$ & $6.23^{\mathrm{B}}$ & $24.27^{\mathrm{C}}$ & $17.10^{\mathrm{G}}$ & $5.37^{\mathrm{EFG}}$ \\
\hline Halwaya & $18.50^{\mathrm{B}}$ & $16.70^{\mathrm{C}}$ & $6.20^{\mathrm{B}}$ & $23.93^{\mathrm{C}}$ & $18.30^{\mathrm{E}}$ & $5.13^{\mathrm{G}}$ \\
\hline Rochdi & $16.67^{\mathrm{E}}$ & $15.13^{\mathrm{G}}$ & $5.30^{\mathrm{D}}$ & $22.17^{\mathrm{DE}}$ & $17.90^{\mathrm{F}}$ & $5.50^{\mathrm{DEF}}$ \\
\hline Deglet Nour & $17.47^{\mathrm{D}}$ & $15.30^{\mathrm{FG}}$ & $5.47^{\mathrm{D}}$ & $21.57^{\mathrm{F}}$ & $16^{\mathrm{H}}$ & $5.10^{\mathrm{G}}$ \\
\hline Baht & $17.90^{\mathrm{C}}$ & $16.23^{\mathrm{E}}$ & $5.33^{\mathrm{D}}$ & $21.10^{\mathrm{G}}$ & $18.60^{\mathrm{D}}$ & $5.53^{\mathrm{DE}}$ \\
\hline Bouhattam & $19.43^{\mathrm{A}}$ & $18.50^{\mathrm{A}}$ & $5.23^{\mathrm{D}}$ & $22.50^{\mathrm{D}}$ & $19.50^{\mathrm{C}}$ & $5.80^{\mathrm{CD}}$ \\
\hline Eguiwa & $19.37^{\mathrm{A}}$ & $16.47^{\mathrm{D}}$ & $5.27^{\mathrm{D}}$ & $21.30^{\mathrm{FG}}$ & $17.83^{\mathrm{F}}$ & $5.57^{\mathrm{DE}}$ \\
\hline Khadhouri & $15.50^{\mathrm{F}}$ & $15.33^{\mathrm{F}}$ & $5.87^{\mathrm{C}}$ & $24.73^{\mathrm{B}}$ & $23.30^{\mathrm{A}}$ & $6.70^{\mathrm{A}}$ \\
\hline
\end{tabular}

date extracts may be due to the phenolic compound that are more effectively extracted with ethanol and methanol than water.

Polyphenols play an important role as antibacterial activity through the precipitation of proteins and inhibition of enzymes of microorganisms. The antibacterial activity of date extracts may be due to the phenolic compound.

\section{Cluster and Principal Component Analyses}

All the measured metabolites (protein, fat, mineral comosition, dietary fiber, sugars, phenolics, flavonoids, anthocyanin, antioxidants, and antibacterial activity) were subjected to principal component analysis (PCA) to identify differences in metabolite profiles among the studied date cultivars.

PCA revealed that the first two principal components (PC1 and PC2) accounted for $54.23 \%$ of the total variance within the data set. PC1 explained 35.11\% and PC2 explained $19.12 \%$ of the data variation. These two principal components separated the studied cultivars into four different groups. The first group consisted of Khadhouri cultivar; the second group of Korkobi; the third group Amari, Deglet Nour, Rochdi, Hammouri, Halwaya, and Eguiwa cultivars; and the fourth group Baht, Bouhattam, Lemsi, and Matata cultivars.

\section{Conclusions}

The present study was carried out for the first time on Tunisian date seed cultivars of Gabes oasis to access their therapeutic and technological values. Considering the polyphenol, flavonoid contents, and the inhibitory capacity of date seed extracts, we can conclude that this by-product of dates could be an excellent source of antioxidants in food and medicine preparation.

\section{Acknowledgements}

The authors are grateful to the Institute of the Arid Regions Medenine, Tunisia for their support. Thanks are also due to the University of Dhofar Oman and Dr. Israr UI Hassen.

\section{Conflict of Interest}

The authors declare no conflict of interest.

\section{References}

1. CHANDRASEKARAN M., ALI H. BAHKALI Valorization of date palm (Phoenix dactylifera) fruit processing by-products and wastes using bioprocess Saudi J Biol Sci 20, 105, 2013.

2. HASNAOUI A., ELHOUMAIZI M. A., HAKKOUN A., WATHELETB. and SINDIE M. Physico-chemical characterization, classification and quality evaluation of date palm fruits of some Moroccan Cultivars. J. Sci. Res. 3 (1), 139, 2011.

3. El-RAHMAN S.N.A, AL-MULHEMSI Characteristic Analysis, Antioxidant Components and Antioxidant Activity of Date Fruits, Date Seeds and Palm Shell. Clin Med Case Rep 1, 101, 2017. 
4. AL-FARSI M., MORRIS, A. and BARON, M. Functional properties of Omani dates (Phoenix dactylifera L.). Acta Hortic. 736, 479, 2007.

5. RANIA M.A., MOHAMEDAISHA S.M., FAGEER MOHAMED M., ELTAYEBISAMOHAMED A. MA Chemical composition, antioxidant capacity, and mineral extractability of Sudanese date palm (Phoenix dactylifera L.) fruits. Food Sci Nutr 2014.

6. ELLEUCH M., BESBES S., ROISEUX O., BLECKER C., DEROMAN C.H., ATTIAE H. Date flesh: chemical composition and characteristics of thedietary fiber, Food Chem. 111, 676, 2008.

7. BESBES S., BLECKER C., DEROMAN C., DRIRA N.E., ATTIA H. Date seeds: chemical composition and characteristic profiles of the lipid fraction. Food Chem; 84, 577e584, 2004.

8. AL-FARSI M., YONG LEE C. Optimization of phenolic and dietary fiber extraction from date seeds, Food Chem 108, 977, 2008

9. ELFALLEH W., TLILIN YAHIA Y., HANNACHI H., NASRI N., FERCHICHI A. Total Phenolic Contents and Antioxidant Activities of Pomegranate Peel, Seed, Leaf and Flower . Nat Prod Commun 6, 2011.

10. MAHMOUDI S., KKALIM BENKHALED A, BENAMOURICHe K. BI, Phenolic and flavonoid contents, antioxidant and antimicrobial activities of leaf extracts from ten Algerian Ficus carica L. varieties, Asian Pac J Trop Biomed. 2016.

11. MUHAMMED NADEEM SALIM-UR-REHMAN, FAQIR MUHAMMED A., IJAZ A.B. Quality evaluation of some pakistani date varieties. Pak. J. Agri. Sci., 48 (4), 305, 2011.

12. HERCH W., KALLEL H., BOUKHCHINA S. Physicochemical properties and antioxidant activity of Tunisian date palm (Phoenix dactylifera L.) oil as affected by different extraction methods. Food Sci 34, 464, 2014.

13. ONI S.O., ADEOSUN A.M., LADOKUN O.A., IGHODARO O.M., OYEDELE M.O. Nutritional and phytochemical profile of niger cultivated date palm (Phoenix Dactilyfera L). J Food Nutr Sci; 3, 114e118, 2015.

14. ASSIERY E.A. Nutritional composition of fruit of 10 date palm (Phoenix dactylifera L.) cultivars grown in Saudi Arabia. J Taibah Univ Sci; 9, 75e79, 2014.

15. ABIOLA A., SARAH O., OSASENAGA M. IGHODARO O., DUROSINLORUN H., OMOTAYO O. Phytochemical, minerals and free radical scavenging profiles of Phoenix dactilyfera L. seed extract. J Taibah Univ Sci 11 (1), 1, 2016.

16. BENMEDDOUR Z., MEHINAGIE E., Le MEURLAY, D., LOUAILECHE H. Phenolic composition and antioxidant capacities of ten Algerian date (Phoenix dactylifera L.) cultivars: a comparative study. J. Funct. Food 5, 346, 2013.

17. EL SOHAIMY S., ABDELWAHAB A., BRENNAN C., ABOUELEININ A. Phenolic content, antioxidant and antimicrobial activities of Egyptian date palm (Phoenix dactylifera L.) fruits. Aust. J. Basic Appl. Sci. 9, 141, 2015.

18. FAHAD A., KASHIF G., MEHMET M.O. Physical and chemical properties, antioxidant activity, total phenol and mineral profile of seeds of seven different date fruit (Phoenix dactylifera L.) varieties. Int J Food Sci Nutr 63, 84, 2012.

19. WALI M.I., GUIZANI N. Health Aspects of Antioxidant Nutrients: A Consice Update. J Agri Res, 1 (1), 000102. 2016.

20. BALIGA S.M., BALIGA B.R.R., KANDATHIL S.M, HARSHITH P.B, KUMAR V. A review of the chemistry and pharmacology of the date fruits (Phoenix dactylifera L.) Food Res Int. 44, 1812, 2011.

21. MOSS J.W. E., RAMJI D.P. Nutraceutical therapies for atherosclerosis. Nat. Rev. Cardiol. 13, 513, 2016. doi: 10.1038/nrcardio.2016.103

22. AL-ALAWI R.A., AL-MASH|IQRI J.H., AL-NADABI J.S.M., AL-SHIHI B.I., BAQI Y. Date Palm Tree (Phoenix dactylifera L.): Natural Products and Therapeutic Options. Front. Plant Sci. 8, 845, 2017.

23. SILVA C.G., METIN C., FAZELI W., MACHADO N.J., DARMOPILL S., LAUNAY P.S., et al. Adenosine receptor antagonists including caffeine alter fetal brain development in mice. Sci. Transl. Med. 5, 197ra104, 2013.

24. KASTER M.P., MACHADO N.J., SILVA H.B., NUNES A., ARDAIS A.P., SANTANA M., et al. Caffeine acts through neuronal adenosine $\mathrm{A} 2 \mathrm{~A}$ receptors to prevent mood and memory dysfunction triggered by chronic stress. Proc. Natl. Acad. Sci. U.S.A. 112, 7833, 2015.

25. SALEH F.A., OTAIBI M.M. Antibacterial Activity of Date Palm (PhoenixDectylifera L.) Fruit at Different Ripening Stages. J Food Process Technol 4, 285, 2013.

26. SHEN X., SUN X., XIE Q., LIU H., ZHAO Y., et al. Antimicrobial effect of blueberry (Vacciniumcorymbosum L.) extracts against the growth of Listeriamonocytogenes and SalmonellaEnteritidis. Food Control 35, 159, 2014. 